\title{
Kurva Produksi Telur di Awal Masa Peneluran Pada Puyuh yang Diberi Ransum dengan Kandungan Protein Berbeda
}

\author{
A. Ratriyanto ${ }^{1, a}$, B. F. Hidayat ${ }^{1}$, N. Widyas $^{1}$ dan S.Prastowo $^{1}$ \\ ${ }^{I}$ Program Studi Peternakan, Fakultas Pertanian, Universitas Sebelas Maret \\ aemail: ratriyanto@staff.uns.ac.id
}

\begin{abstract}
Abstrak
Penelitian bertujuan untuk mengkaji pola produksi dan aplikasi model regresi logistik produksi telur puyuh yang diberi ransum dengan level protein berbeda. Sebanyak 225 ekor puyuh didistribusikan dalam 3 perlakuan dan 5 ulangan; jumlah puyuh masing-masing ulangan 15 ekor. Perlakuan yang diberikan adalah level protein kasar (PK) dalam ransum sebesar 16,5\% (P1), 18\% (P2) dan 19,5\% (P3). Data produksi telur diambil sejak awal peneluran pada masa adaptasi dan selama dua periode produksi telur $(2 \times 28$ hari) pada masa perlakuan. Data dianalisis menggunakan program R. Perlakuan P2 dan P3 menghasilkan produksi telur yang lebih tinggi daripada P1 $(\mathrm{P}<0.05)$. Model logistik produksi telur puyuh menunjukkan bahwa puncak produksi tertinggi dicapai oleh P3 sedangkan rentang dan laju produksi terbesar dicapai P1. Data aktual produksi telur memiliki kesesuaian (fitness) yang tinggi $\left(\mathrm{R}^{2}=0,92-0,97\right)$ dengan model logistik. Berdasarkan hasil tersebut, disimpulkan bahwa semakin tinggi protein kasar menghasilkan produksi telur yang tinggi. Model regresi logistik dapat digunakan untuk menganalisis pengaruh perlakuan biologis terhadap produksi telur puyuh serta memiliki kesesuaian yang tinggi dengan data aktual.
\end{abstract}

Kata kunci: kesesuaian, model matematika, produksi telur puyuh, protein kasar

\section{Egg production curve at early production period in quails submitted to different protein regimes}

\begin{abstract}
The objective of this research was to investigate the egg production pattern and apply the logistic model on the egg production of quails submitted to different protein regimes. The experimental population comprised of 225 laying quails which were distibuted to three treatments and five replicates with 15 quails each. The treatments were crude protein (CP) levels in the diet, namely $16.5 \%(\mathrm{P} 1), 18 \%(\mathrm{P} 2)$ and $19.5 \%(\mathrm{P} 3)$. Egg production data were recorded since the onset of lay at adaptation period and two periods of 28 days during feeding treatments $(2 \times 28$ days). The data were submitted to analysis of variance and mathematical modeling using the R program. The P2 and $\mathrm{P} 3$ treatments produced higher egg production than $\mathrm{P} 1(\mathrm{P}<0.05)$. Logistic model showed that $\mathrm{P} 3$ had highest peak production while $\mathrm{P} 1$ had the largest production rate and production range. The logistic model showed high fitness with the actual egg production data $\left(\mathrm{R}^{2}=0,92-0,97\right)$. It can be concluded thet feeding with high CP produced more eggs than low CP. Logistic model could be applied to analyze the effect of biological treatment in egg production of quails and had high fitness with the actual data.
\end{abstract}

Key words: fitness, mathematical modelling, egg production quail, crude protein

\section{Pendahuluan}

Puyuh (Cortunix cortunic japonica) merupakan salah satu ternak unggas petelur yang memiliki potensi besar untuk dibudidayakan. Puyuh mengalami kematangan seksual yang cepat, ditandai dengan awal produksi telur pada umur sekitar 42 hari (Kaye et al., 2017; Piao et al., 2004). Produksi telur meningkat dengan cepat dan mencapai puncak produksi, diikuti dengan produksi yang stabil dan selanjutnya menurun secara bertahap (Narinc et al., 
2014). Puyuh dapat menghasilkan telur antara 250-300 butir selama setahun masa produksi (Narinc et al., 2013).

Kurva produksi telur pada dasarnya sudah diatur secara genetis, tetapi produksi telur dapat dimodifikasi oleh faktor lingkungan, salah satunya adalah faktor nutrisi (Pavlidis et al., 2002; Ratriyanto \& Mosenthin, 2018). Produksi telur merupakan deposisi protein di dalam tubuh puyuh. Protein kasar (PK) memiliki peran yang sangat penting dalam penyusunan ransum dan menjadi penentu dalam evaluasi performa ternak (Dairo et al., 2010). Pemberian ransum puyuh dengan kandungan PK yang rendah dapat menurunkan produksi telur (Garcia et al., 2005). Sebaliknya kandungan PK yang terlalu tinggi dalam ransum menyebabkan banyak protein yang terbuang dan menimbulkan cekaman panas akibat hasil proses metabolisme sehingga dapat menurunkan performa puyuh ( $\mathrm{Li}$ et al., 2011).

Model matematika banyak digunakan untuk menginterpretasikan pola produksi ternak, salah satunya produksi telur (Narushin \& Takma, 2003; Savegnago et al., 2011). Model matematika digunakan sebagai kontrol terhadap produksi telur aktual dan menggambarkan produksi telur sepanjang waktu. Interpretasi produksi telur dengan model matematika dapat digunakan untuk menganalisis pengaruh perlakuan biologis terhadap produksi telur dan memprediksi produksi telur (Savegnago et al., 2012). Diantara model matematika yang digunakan adalah Gamma, McNally, Compartmental, Adams-Bell dan Logistik (Narinc et al., 2013, 2014; Savegnago et al.,
2012). Model regresi logistik memiliki kesesuaian yang baik dengan data aktual dalam memodelkan kurva sigmoid pada awal periode produksi telur (Anang et al., 2007; Otwinowska-Mindur et al., 2016). Meskipun model matematika telah banyak digunakan untuk membuat model produksi telur, akan tetapi aplikasinya belum pernah digunakan untuk menganalisis produksi telur puyuh yang diberi ransum dengan kandungan PK yang berbeda. Berdasarkan uraian tersebut penelitian ini bertujuan untuk mengkaji pola produksi dan mengaplikasikan model regresi logistik pada produksi telur puyuh yang diberi ransum dengan kandungan PK berbeda.

\section{Materi dan Metode}

\section{Desain penelitian dan ransum perlakuan}

Penelitian menggunakan 225 ekor puyuh petelur (Coturnix coturnix japonica) berumur 25 hari yang didistribusikan ke dalam tiga perlakuan dengan lima ulangan, masing-masing ulangan berisi 15 ekor puyuh. Perlakuan yang diberikan adalah pemberian ransum dengan level PK sebesar $16,5 \%$ (P1), 18,0\% (P2) dan 19,5\% (P3). Kandungan nutrien lainnya disusun sesuai rekomendasi Nutrition Research Council (1994). Kandungan nutrien ransum puyuh fase produksi dapat dilihat pada Tabel 1.

Selama periode grower (sampai umur 41 hari) puyuh diberi ransum komersial. Selama masa adaptasi pada awal produksi telur (umur 42-62 hari), puyuh diberi ransum dengan PK $18 \%$, sedangkan pada periode perlakuan (63-118 hari) puyuh diberi ransum perlakuan dengan PK berbeda sesuai dengan perlakuan yang diberikan.

Tabel 1. Kandungan nutrien ransum perlakuan

\begin{tabular}{lrrr} 
& \multicolumn{3}{c}{ Protein Kasar (\%) } \\
\cline { 2 - 4 } \multicolumn{1}{c}{ Nutrien } & \multicolumn{1}{c}{16,5} & \multicolumn{1}{c}{19,5} \\
\hline Energi metabolis (kkal/kg) & 2800,50 & 2800,20 & 2800,10 \\
Protein kasar (\%) & 16,50 & 18,01 & 19,51 \\
Kalsium (\%) & 3,40 & 3,41 & 3,40 \\
Fosfor (\%) & 0,61 & 0,63 & 0,62 \\
Lisin (\%) & 1,13 & 1,14 & 1,14 \\
Metionin (\%) & 0,41 & 0,41 & 0,41 \\
\hline
\end{tabular}




\section{Manajemen dan analisis data}

Pengambilan data produksi telur dilakukan sejak awal bertelur pada masa adaptasi dan selama dua periode produksi telur $(2 \times 28$ hari) pada masa perlakuan. Data produksi telur dipisahkan berdasarkan perlakuan yang diberikan. Data ditata sedemikian rupa sehingga dapat di input kedalam program $\mathrm{R}$ yang digunakan untuk analisis data. Selanjutnya data dianalisis untuk membuat model regresi logistik. Analisis dilakukan dengan menggunakan custom script program R (R Core Team, 2019).

Data produksi telur aktual selama masa adaptasi dan perlakuan dianalisis menggunakan analisis variansi untuk mengetahui variasi antar perlakuan. Model matematika yang digunakan adalah sebagai berikut:

$$
Y_{i j}=\mu+A_{i}+\varepsilon_{i j}
$$

Dimana: $\mathrm{Y}_{\mathrm{ij}}=$ nilai pengamatan pada perlakuan ke-i dan ulangan ke-j, $\mu=$ nilai tengah umum, $A_{i}=$ pengaruh level protein $\mathrm{ke}-\mathrm{i}$, dan $\varepsilon_{\mathrm{ij}}=$ pengaruh galat percobaan perlakuan ke-i dan ulangan ke-j.

Selanjutnya data aktual produksi telur puyuh dianalisis dengan model regresi logistik. Model ini digunakan karena dapat mengevaluasi pengaruh perlakuan, umur dan interaksi antara keduanya (Mazzuco et al., 2011). Persamaan model regresi logistik (Ott, Longnecker, Taylor, \& Payumo, 2010) yang digunakan adalah sebagai berikut:

$$
Y_{t}=\frac{\alpha}{1+\beta \exp [k t]}
$$

Dimana: $Y_{t}=$ produksi yang dicari, $\alpha=$ puncak produksi, $\beta=$ rentang produksi, exp $=$ fungsi eksponensial, $\mathrm{k}=$ laju produksi, $\mathrm{t}=$ waktu produksi.

Kesesuaian antara kurva produksi telur aktual dan kurva hasil model matematika diuji menggunakan nilai koefisien determinasi (Ott et al., 2010).

\section{Hasil dan Pembahasan}

\section{Eksplorasi data dan hasil analisis variansi}

Data produksi telur di dokumentasikan mulai dari awal puyuh bertelur sampai akhir periode kedua masa perlakuan (Tabel 2). Data yang telah didokumentasikan dan dianalisis menggunakan program $\mathrm{R}$ untuk memperoleh kondisi data secara umum dan diinterpretasikan dalam bentuk kurva. Hal ini dilakukan agar memudahkan analisis data dan mengetahui pengaruh perlakukan terhadap pola produksi telur harian.

Produksi telur pada periode adaptasi berawal ketika puyuh mencapai kematangan seksual yang ditandai dengan produksi telur pertama kali sampai dengan produksi mencapai $50 \%$. Periode perlakuan dimulai setelah produksi telur lebih dari $50 \%$ pada umur 63 hari dan berakhir pada akhir periode kedua produksi telur pada umur 118 hari. Puyuh pada periode adaptasi diberi ransum yang sama untuk menyeragamkan produksi telur secara keseluruhan dan pada periode perlakuan diberi ransum sesuai dengan perlakuan masing-masing. Data produksi telur puyuh pada masa adaptasi menunjukkan produksi telur tidak mencapai $100 \%$ dibandingkan dengan puyuh pada periode perlakuan. Hal ini disebabkan karena puncak produksi puyuh dicapai pada umur 11 minggu di masa perlakuan (Kaye et al., 2017).

Hasil analisis variansi untuk periode adaptasi menunjukkan bahwa tidak ada perbedaan antar kelompok perlakuan $(\mathrm{P}>0,05)$ akibat pemberian ransum yang seragam pada seluruh puyuh. Hasil analisis variansi pada periode perlakuan menunjukkan bahwa puyuh yang diberi ransum dengan level PK yang berbeda menunjukkan adanya pengaruh terhadap produksi telur $(\mathrm{P} \leq 0,05)$. Puyuh yang diberi ransum dengan level PK 19,5\% memiliki rata-rata produksi lebih tinggi daripada $\mathrm{PK}$ $16,5 \%$, tetapi tidak berbeda dengan PK $18,0 \%$. Hal ini disebabkan karena tingginya protein yang tercerna dideposisikan untuk memproduksi telur (Ratriyanto et al., 2017). Protein merupakan komponen utama penyusun telur (Ding et al., 2016). Hasil ini sejalan dengan peneliti sebelumnya bahwa meningkatknya level PK 18\% menjadi 22\% dalam ransum dapat meningkatkan produksi telur puyuh (Azghadi et al., 2014). Peningkatan level PK dalam ransum dari $16 \%$ sampai $20 \%$ dapat meningkatkan produksi telur puyuh (Garcia et al., 2005). 
Tabel 2. Eksplorasi data dan hasil analisis variansi

\begin{tabular}{cccccc}
\hline \multirow{2}{*}{ Ransum } & \multirow{2}{*}{ Periode } & Jumlah & \multicolumn{3}{c}{ Data Produksi Telur (\%) } \\
\cline { 4 - 6 } & & Data & Min & Max & Rata-rata \\
\hline P2 & Adaptasi & 105 & 0,00 & 68,00 & $26,07 \pm 20,34$ \\
P2 & Adaptasi & 105 & 0,00 & 56,00 & $22,68 \pm 19,01$ \\
P2 & Adaptasi & 105 & 0,00 & 68,00 & $24,76 \pm 20,28$ \\
Nilai P & & & & & $>0,05$ \\
P1 & Perlakuan & 280 & 20,00 & 100,00 & $62,63 \pm 16,02^{\mathrm{a}}$ \\
P2 & Perlakuan & 280 & 26,67 & 100,00 & $64,01 \pm 16,12^{\mathrm{ab}}$ \\
P3 & Perlakuan & 280 & 14,29 & 100,00 & $66,08 \pm 18,39^{\mathrm{b}}$ \\
Nilai P & & & & & $=0,05$ \\
P1 & Keseluruhan & 385 & 0,00 & 100,00 & $52,66 \pm 23,76$ \\
P2 & Keseluruhan & 385 & 0,00 & 100,00 & $52,74 \pm 25,03$ \\
P3 & Keseluruhan & 385 & 0,00 & 100,00 & $54,81 \pm 26,39$ \\
Nilai P & & & & & $>0,05$ \\
\hline
\end{tabular}

$\mathrm{P} 1=$ protein $\operatorname{kasar} 16,5 \%, \mathrm{P} 2=$ protein kasar 18,0\%, P3 = protein kasar 19,5\%

${ }_{\mathrm{a}, \mathrm{b}}$ superskrip yang berbeda pada kolom yang sama menunjukkan perbedaan yang nyata $(\mathrm{P} \leq 0,05)$

Gambar 1 menyajikan kurva aktual produksi telur puyuh yang menunjukan besarnya variasi produksi telur puyuh akibat faktor non-genetik dengan tetap mengikuti pola tertentu yang disebabkan oleh faktor genetik. Produksi telur puyuh yang sangat bervariasi berhubungan dengan faktor genetik dan non-genetik (Kaye et al., 2017). Variasi produksi telur puyuh akibat faktor non-genetik diantaranya disebabkan oleh faktor kesehatan, pemenuhan nutrien, manajemen pemeliharaan dan kondisi lingkungan seperti pencahayaan, suhu, kelembaban, iklim dan cuaca (Shanaway, 1994).
Kurva produksi telur puyuh $\mathrm{P} 1$ di masa awal puncak produksi pada umur 70 hari menunjukkan fluktuasi yang besar. Hal ini disebabkan karena protein yang dideposisikan dalam albumen belum terpenuhi akibat rendahnya protein yang tersedia sehingga puyuh menunda produksi telur hingga kebutuhan protein albumen tercukupi (Gous \& Nonis, 2010). Rendahnya produksi telur puyuh yang diberi ransum dengan level protein 16\% akibat terjadinya defisiensi protein dalam memproduksi telur, terutama pada puncak produksi (Garcia et al., 2005).

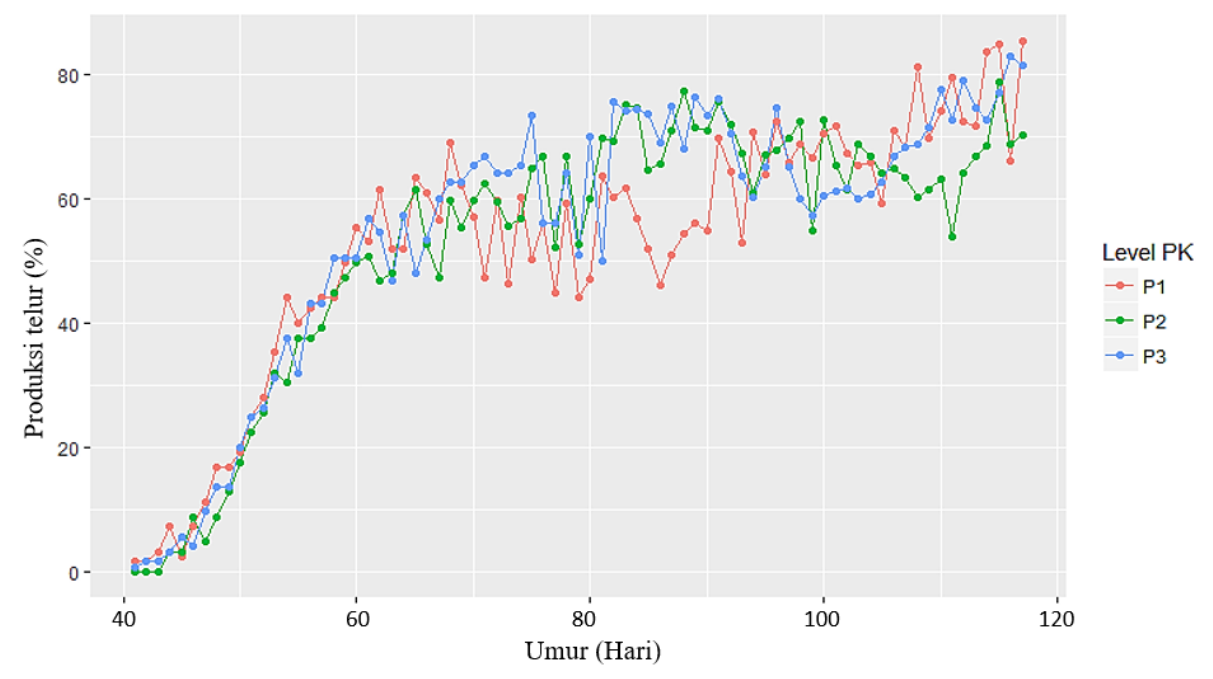

Gambar 1. Kurva aktual produksi telur puyuh 


\section{Model logistik produksi telur puyuh dan kesesuaian model}

Kurva produksi telur hasil prediksi dengan model regresi logistik dapat dilihat pada Gambar 2. Model logistik dapat digunakan untuk membuat model produksi telur. Aplikasi model regresi logistik pada produksi telur puyuh digunakan sebagai kontrol dari fluktuasi produksi telur harian. Model regresi logistik yang digunakan dalam penelitian ini mengombinasikan masa penurunan produksi telur pada model kompartemen dan masa peningkatan produksi telur pada model Adams-Bell yang serupa dengan model logistik pertumbuhan berat badan. Meskipun tidak sebaik model pertumbuhan berat badan, model produksi telur dapat digunakan untuk interpretasi biologis produksi telur. Kombinasi dari kedua model ini dilakukan karena model kompartemen dapat digunakan untuk menginterpretasikan data secara biologis dan model Adams-Bell dapat digunakan untuk menduga produksi telur sejak awal koleksi data secara akurat (Narinc et al., 2014).

Kurva produksi telur puyuh dimulai dari awal kematangan seksual, meningkat cepat mencapai puncak produksi telur, mengikuti pola linier beberapa saat dan kemudian menurun menuju akhir produksi (Narinc et al., 2013). Puyuh mencapai kematangan seksual ditandai dengan pertama kali puyuh bertelur (Ratriyanto, 2018). Puyuh P1, P2 dan P3 masing-masing mulai bertelur pada umur 42, 45 dan 42 hari. Puyuh mencapai kematangan seksual pada umur 35-45 hari. Semua kelompok perlakuan mencapai puncak produksi telur pada umur 11 minggu sesuai dengan laporan Piano et al. (2004) yang menyatakan bahwa puyuh mencapai puncak produksi telur pada umur 10-12 minggu (Piao et al., 2004).

Kurva model produksi telur penting untuk penentuan level nutrien pakan yang berkaitan dengan bentuk kurva dan laju produksi telur sehingga mampu mengefisienkan biaya pakan yang dikeluarkan dibandingkan dengan pendapatan penjualan telur (Johnston \&
Gous, 2007; Narushin \& Takma, 2003). Bentuk kurva sigmoid pada awal masa produksi menunjukkan terjadinya perubahan alokasi protein di dalam tubuh. Prioritas alokasi protein dalam tubuh puyuh mengalami perubahan seiring dengan bertambahnya umur puyuh. Pada masa pertumbuhan, puyuh memprioritaskan alokasi protein untuk kebutuhan pokok, pertumbuhan jaringan tubuh dan pertumbuhan bulu. Saat puyuh mencapai kematangan seksual, protein yang digunakan untuk pertumbuhan jaringan tubuh puyuh berubah secara bertahap dialokasikan untuk memproduksi telur dan protein secara penuh dialokasikan untuk produksi telur puyuh saat mencapai puncak produksi (Gous \& Nonis, 2010).

Aplikasi model regresi logistik pada produksi telur puyuh dapat dilihat pada Tabel 3. Puncak produksi adalah produksi telur maksimal yang dicapai selama 5 hari berturut-turut tanpa mengalami peningkatan (Anang et al., 2007). Hasil aplikasi model regresi logistik menunjukkan bahwa puncak produksi telur mengalami peningkatan secara berurutan seiring dengan meningkatnya PK ransum. Hal ini disebabkan karena tingginya protein yang tercerna mengakibatkan banyak protein yang dideposisikan untuk perkembangan folikel pada organ reproduksi sehingga puncak produksi dan potensi genetik terekspresikan secara optimal (Gous \& Nonis, 2010). Hal ini dibuktikan dengan puncak produksi pada P1 yang rendah, sebaliknya puncak produksi paling tinggi dicapai P3.

Laju produksi telur merupakan kecepatan pertambahan dan penurunan produksi telur (Anang et al., 2007). Laju produksi telur puyuh paling besar ditunjukkan oleh puyuh pada P1. Hal ini disebabkan karena puyuh mencapai puncak produksi lebih awal dan memiliki puncak produksi yang lebih rendah daripada $\mathrm{P} 2$ dan P3. Rentang produksi terbesar ditunjukkan oleh P1 dan rentang produksi terkecil ditunjukkan oleh P2. 

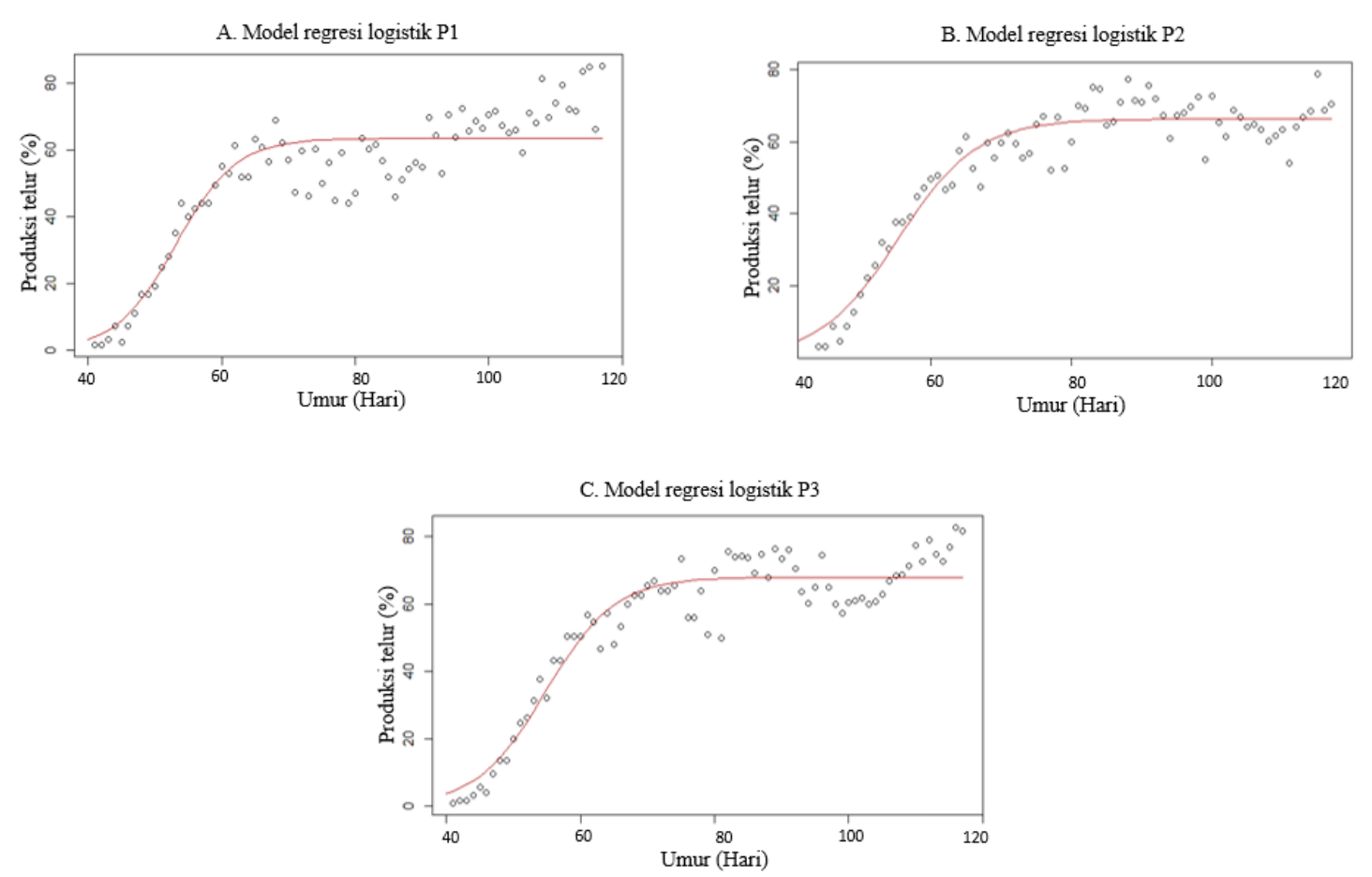

Gambar 2. Model regresi logistik produksi telur puyuh pada P1 (A), P2 (B) dan P3 (C)

Tabel 3. Hasil aplikasi model regresi logistik pada produksi telur puyuh

\begin{tabular}{lccc}
\hline & P1 & P2 & P3 \\
\hline Puncak produksi (\%) & 63,45 & 66,23 & 67,95 \\
Laju produksi & 0,22 & 0,18 & 0,19 \\
Rentang produksi & 18,58 & 15,19 & 17,42 \\
Koefisien determinasi $\left(\mathrm{R}^{2}\right)$ & 0,92 & 0,97 & 0,96 \\
\hline
\end{tabular}

$\mathrm{P} 1=$ protein kasar $16,5 \%, \mathrm{P} 2=$ protein kasar $18 \%, \mathrm{P} 3=$ protein $\mathrm{kasar} 19,5 \%$

Kesesuaian hasil aplikasi model logistik pada data aktual produksi telur puyuh diuji dengan nilai koefisien determinasi $\left(\mathrm{R}^{2}\right)$. Kesesuaian model logistik produksi telur puyuh pada $\mathrm{P} 2\left(\mathrm{R}^{2}=0,97\right)$ dan P3 $\left(\mathrm{R}^{2}=0,96\right)$ lebih tinggi daripada $\mathrm{P} 1$ $\left(\mathrm{R}^{2}=0,92\right)$, walaupun demikian, semua nilai $\mathrm{R}^{2}$ tersebut dikategorikan tinggi (lebih dari $0,9)$. Nilai $\mathrm{R}^{2}$ yang tinggi menunjukkan kesesuaian yang baik dengan data aktual produksi telur (Anang, Indrijani, \& Sujana, 2017; Narushin \& Takma, 2003). Selisih nilai $\mathrm{R}^{2}$ yang terjadi dalam model matematika diakibatkan karena perbedaan himpunan data aktual produksi telur yang dicocokan dengan model matematika (Anang et al., 2017, 2007).

\section{Kesimpulan}

Peningkatan protein kasar dalam ransum mampu meningkatkan produksi telur puyuh. Model regresi logistik terbukti dapat digunakan untuk menganalisis pengaruh perlakuan biologis terhadap produksi telur puyuh dengan tingkat kesesuaian yang tinggi terhadap data produksi telur aktual.

\section{Daftar Pustaka}

Anang, A., Indrijani, H., \& Sujana, E. (2017). Mathematical model of growth of two purelines of Padjadjaran female quail aged 0 to 6 weeks. Journal of the Indonesian Tropical Animal Agriculture, $\quad 42(2), \quad 66$. https://doi.org/10.14710/jitaa.42.2.6671

Anang, A., Indrijani, H., \& Sundara, T. A. 
(2007). Model Matematika Kurva Produksi Telur Ayam Broiler Breeder Parent Stock. Jurnal Ilmu Ternak, 7(1), 6-11.

Azghadi, M. A., Kermanshahi, H., \& Golian, A. (2014). The effect of dietary energy and protein levels on growth performance and antibody responses of offspring of laying Japanese quails. Iranian Journal of Applied Animal Science, 4(2007), 185-190.

Dairo, F. A. S., Adesehinwa, A. O. K., Oluwasola, T. A., \& Oluyemi, J. A. (2010). High and low dietary energy and protein levels for broiler chickens. African Journal of Agricultural Research, 5(15), 2030-2038. https://doi.org/10.5897/AJAR10.254

Ding, Y., Bu, X., Zhang, N., Li, L., \& Zou, X. (2016). Effects of metabolizable energy and crude protein levels on laying performance, egg quality and serum biochemical indices of Fengda1 layers. Animal Nutrition, 2(2), 9398.

https://doi.org/10.1016/j.aninu.2016.0 3.006

Garcia, E., Mendes, A., Pizzolante, C., Saldanha, E., Moreira, J., Mori, C., \& Pavan, A. (2005). Protein, methionine+cystine and lysine levels for Japanese quails during the production phase. Revista Brasileira de Ciência Avícola, 7(1), 11-18. https://doi.org/10.1590/S1516635X2005000100002

Gous, R. M., \& Nonis, M. K. (2010). Modelling egg production and nutrient responses in broiler breeder hens. The Journal of Agricultural Science, 148(3), 287-301. https://doi.org/10.1017/S00218596100 00183

Johnston, S. A., \& Gous, R. M. (2007). A mechanistic, stochastic, population model of egg production. British Poultry Science, 48(2), 224-232. https://doi.org/10.1080/000716607012 27493

Kaye, J., Luka, S. J., Akpa, G. N., \& Adeyinka, I. A. (2017). Egg production pattern of Japanese quail (Coturnix coturnix japonica ) in Northern Guinea
Savannah Zone of Nigeria. International Journal of Innovative Research and Advanced Studies, 4(1), 93-97.

Li, Y. X., Qang, Y. Q., Pang, Y. Z., Li, J. X., Xie, X. H., Guo, T. J., \& Li, W. Q. (2011). The effect of crude protein level in diets on laying performance, nutrient digestibility of yelow quails. International Journal of Poultry Science, 10(2), 110-112.

Mazzuco, H., Avila, V. S., Coldebella, A., Mores, R., Jaenisch, F. R. F., \& Lopes, L. S. (2011). Comparison of the effect of different methods of molt: Production and welfare evaluation. Poultry Science, 90(12), 2913-2920. https://doi.org/10.3382/ps.2011-01670

Narinc, D., Karaman, E., Aksoy, T., \& Firat, M. Z. (2013). Investigation of nonlinear models to describe long-term egg production in Japanese quail. Poultry Science, 92, 1676-1682. https://doi.org/10.3382/ps.2012-02511

Narinc, D., Uckardes, F., \& Aslan, E. (2014). Egg production curve analyses in poultry science. World's Poultry Science Journal, 70(4), 817-828. https://doi.org/10.1017/s00439339140 00877

Narushin, V. G., \& Takma, C. (2003). Sigmoid model for the evaluation of growth and production curves in laying hens. Biosystems Engineering, 84(3), 343-348.

https://doi.org/10.1016/S15375110(02)00286-6

Nutrition Research Council. (1994). Nutrient Requirements of Poultry (9th ed.). Washington DC: National Academic Press. https://doi.org/10.17226/2114

Ott, R. L., Longnecker, M., Taylor, M., \& Payumo, M. A. (2010). An Introduction to Statistical Methods and Data Analysis Sixth Edition. USA: Brooks/Cole, Cengage Learning.

Otwinowska-Mindur, A., Gumułka, M., \& Kania-Gierdziewicz, J. (2016). Mathematical Models for Egg Production in Broiler Breeder Hens. Annals of Animal Science, 16(4), 1185-1198. 
https://doi.org/10.1515/aoas-20160037

Pavlidis, H. O., Price, S. E., \& Siegel, P. B. (2002). Associations between egg production and clutch length in four selected lines of chickens. Journal of Applied Poultry Research, 11(3), 304307.

https://doi.org/10.1093/japr/11.3.304

Piao, J., Okamoto, S., Kobayashi, S., Wada, Y., \& Maeda, Y. (2004). Purebred and crossbred performances from a Japanese quail line with very small body size. Animal Research, EDP Sciences Res, 53(53), 145-153. https://doi.org/10.1051/animres:20040 07

R Core Team. (2019). R: A Language and Environment for Statistical Computing. Vienna: R Foundation for Statistical Computing.

Ratriyanto, A. (2018). Pola produksi telur puyuh yang diberi ransum disuplementasi betain dan metionin. Caraka Tani: Journal of Sustainable Agriculture, 2570(1), 1-7. https://doi.org/http://dx.doi.org/10.209 61/carakatani.v33i1.19354

Ratriyanto, A., Indreswari, R., \& Nuhriawangsa, A. M. P. (2017). Effects of dietary protein level and betaine supplementation on nutrient digestibility and performance of Japanese quails. Revista Brasileira de Ciencia Avicola, 19(3), 445-454. https://doi.org/10.1590/1806-90612016-0442

Ratriyanto, A., \& Mosenthin, R. (2018). Osmoregulatory function of betaine in alleviating heat stress in poultry. Journal of Animal Physiology and Animal Nutrition, 102, 1634-1650.

Savegnago, R. P., Cruz, V. a. R., Ramos, S. B., Caetano, S. L., Schmidt, G. S., Ledur, M. C., ... Munari, D. P. (2012). Egg production curve fitting using nonlinear models for selected and nonselected lines of White Leghorn hens. Poultry Science, 91(11), 29772987. https://doi.org/10.3382/ps.201202277

Savegnago, R. P., Nunes, B. N., Caetano, S. L., Ferraudo, A. S., Schmidt, G. S., Ledur, M. C., \& Munari, D. P. (2011). Comparison of logistic and neural network models to fit to the egg production curve of White Leghorn hens. Poultry Science, 90(3), 705-711. https://doi.org/10.3382/ps.2010-00723

Shanaway, M. M. (1994). Quail Production Systems: A Review. Rome: FAO. 